\title{
TRAJNOSTNI RAZVOJ IN PODJETNIŠTVO V TRIGLAVSKEM NARODNEM PARKU
}

\author{
Žarko A. Mlekuž
}

Izvleček

UDK 334.722:502.72(497.4 Triglavski narodni park)

Prispevek ocenjuje stanje podjetništva v Triglavskem narodnem parku. Varovanje narave in podjetništvo sta lahko v neprestanem sporu, vendar je sožitje možno in obojestransko koristno. Edini pravilni odgovor je uveljavljanje trajnostnega razvoja.

Ključne besede: trajnostni razvoj, podjetništvo, statični okvir podjetništva, Triglavski narodni park, Julijske Alpe, Slovenija.

\section{SUSTAINABLE DEVELOPEMENT AND ENTERPRENEURSHIP IN THE TRIGLAV NATIONAL PARK}

\section{Abstract:}

The paper describes the enterpreneurship in Triglav national parc. Nature conservation and enterpreneurship can be in permanent conflict, but coesistence is possible and even mutually benefitiary. The proper issue is sustinable develpement.

Key words: sustainable developement, enterpreneurship, static frame of entrprepreneurship, iglav national parc, Julian Alps, Slovenia

\footnotetext{
* Dipl. oec., svetovalec podjetništva v turizmu; Svetovanje, razvojni projekti, Brdo 62, 5230 Bovec, Slovenija
} 


\section{UVOD}

Podjetništvo je eden izmed najpomembnejših spodbujevalcev razvoja. Na podeželju, kjer se je močno znižal delež prebivalstva, ki se ukvarja s kmetijstvom, postaja malo podejtništvo vedno bolj bolj tudi najpomembnejši dejavnik ohranjanja poseljenosti podeželja in njegovega gospodarskega razvoja. V naravnih parkih je gospodarski razvoj dopusten le na nekaterih območjih in pod določenimi pogoji. Okvir, znotraj katerega se lahko razvije podjetniška dejavnost, je $\mathrm{V}$ največji meri določen $\mathrm{z}$ varstveno skupino in z načeli trajnostnega razvoja.

Varstvena skupina in vse omejitve, ki so pogojene z njo, so določene v zakonu o ustanovitvi naravnega parka. To pomeni, da so pogoji gospodarjenja in podjetniške možnosti z njim trajno določeni. Spremenijo se lahko le s spremembami zakona, ki običajno niso pogoste. Glede na to sem pogoje za razvoj (ali omejevanje) podjetništva, ki ga postavlja zakon, poimenoval statični okvir podjetništva.

Razvoju je že samemu po sebi imanentna sprememba. Podjetništvo, kot izrazita ustvarjalna in dinamična dejavnost je eden izmed nosilcev razvojnih sprememb. V naravnih parkih, kjer je temeljnega pomena varstvo narave, mora biti tudi razvoj $\mathrm{v}$ harmoniji z naravo. Ekonomija in ekologija morata biti uravnotežena dela istega sistema. Vsak razvoj zanesljivo ni v skladu z okoljem oziroma naravo. Lahko celo trdimo, da so prevladujoče usmeritve razvitih tržnih ekonomij večinoma v nasprotju $\mathrm{z}$ njo. Kot smo že ugotovili, je model trajnostnega razvoja tista oblika razvoja, ki je dopustna in večinoma tudi zaželena $\mathrm{v}$ naravnih parkih. Načela in usmeritve trajnostnega razvoja so tako tudi okvir delovanja podjetništva $\mathrm{v}$ naravnih parkih. Model trajnostnega razvoja sem, nasprotno zakonskemu statičnemu okviru, poimenoval dinamični okvir podjetništva $\mathrm{v}$ naravnih parkih. $\mathrm{V}$ nadaljevanju podrobneje razčlenjujem pogoje podjetništva, tako $\mathrm{s}$ statičnega kakor tudi dinamičnega vidika.

\section{STATIČNI OKVIR PODJETNIŠTVA}

Ustanavljanje naravnih parkov je ves čas povezano z oblikovanjem zakonodaje na področju varstva narave in ustanavljanja zavarovanih območij. Zakonodaja je vedno rezultat določenih družbenih in ekonomskih razmer v neki državi. To vpliva na to, da imajo različne države zelo različno zakonodajo tudi na naravovarstvenem področju.

Slovenija, ki se nahaja $\mathrm{v}$ obdobju velikih ekonomskih in družbenih sprememb, še vedno oblikuje temeljno zakonodajo tudi na področju varstva narave. Sprejemajo in 
potrjujejo se različni mednarodni sporazumi s tega področja. Prav tako se dograjuje pravni sistem Slovenije. Temeljni zakon pravnega sistema varstva okolja, Zakon o varstvu okolja (Ur. 1. RS 32/93), je bil sprejet leta 1993. Veljaven je še Zakon o varstvu naravne in kulturne dediščine (Ur. 1. 1-3/81), ki ureja le določeno področje varovanja. Poleg njega ima Slovenija še nekaj sektorskih zakonov (na primer Zakon o gozdovih). Ker so omenjeni zakoni neusklajeni z novejšimi usmeritvami varstva okolja in urejajo področje nesistematično, je v pripravi Zakon o varstvu narave, ki naj bi bil sprejet še v letu 1998.

Statični okvir podjetništva v naravnih parkih je torej še v nastajanju, vendar že lahko opozorimo na ključne usmeritve, ki $\mathrm{v}$ veliki meri določajo pogoje razvoja podjetništva $\mathrm{v}$ naravnih parkih. Na podlagi analize obstoječe zakonodaje in že sprejetih gradiv navajam glavne ugotovitve:

- $\quad$ Narava je celotnost materialnega sveta in sestav z naravnimi zakoni med seboj povezanih in soodvisnih delov in procesov. Človek je sestavni del narave« (1.1.točka 5.člena Zakona o varstvu narave). Navedeni citat pomeni, da moramo človeka in s tem tudi njegovo gospodarsko - podjetniško dejavnost, obravnavati kot del enovitega sistema in ne nekaj, kar je zunaj ali nad naravo. To načelo se mora na določen način uveljavljati tudi v naravnih parkih.

- $\quad$ Merilo vseh ravnanj in norm varstva okolja je človekovo zdravje, počutje in kakovost njegovega življenja ter preživetje in počutje živih organizmov« (4. Odstavek 1. člena Zakona o varstvu okolja). Tudi to merilo podpira predhodno zapisano načelo.

- V gradivu »Ustanavljanje in upravljanje naravnih parkov v Sloveniji« je na četrti strani zapisano: «Odločitev za varstvo narave pomeni odločitev za sonaravni, uravnoteženi razvoj, temelječ na načelu trajnosti, ki omogoča varstvo strukture, funkcije in raznolikosti naravnih sistemov, ohranitev ekosistemov, njihove pestrosti $\mathrm{v}$ vseh pojavnih oblikah, po drugi strani pa zagotavlja izboljšanje kakovosti človekovega življenja.« Kakovost življenja v naravnih parkih pa je seveda tudi možnost dela in ustvarjanja za krajevno prebivalstvo.

- Razvojni vidik varstva narave se lahko uresničuje le z upravljanjem naravnih parkov tako, da so naravovarstvena načela vgrajena $\mathrm{v}$ sisteme in postopke vseh dejavnosti, ki se izvajajo $\mathrm{v}$ naravi, kot so kmetijstvo, gozdarstvo, turizem, energetika, raziskovalna dejavnost, izobraževanje. 


\subsection{Zakon o Triglavskem narodnem parku in razvoj}

Zakon o Triglavskem narodnem parku (Ur. 1. SRS, št. 17/81) je bil sprejet leta 1981. Takrat seveda še ni bilo govora o trajnostnem razvoju pa tudi tržnega gospodarstva ni bilo. Kljub temu da so bile družbene in ekonomske razmere bistveno drugačne od današnjih, ima zakon, katerega osnovni namen je bilo varovanje naravnih in kulturnih vrednot osrednjega območja Julijskih Alp, tudi nekaj členov, ki govorijo o razvoju.

Analiziral sem zakon z vidika možnosti, ki jih daje razvoju podjetništva. Navajam tiste člene zakona, ki se nanašajo na gospodarske dejavnosti in razvoj:

- 1.ČLEN: »Z namenom, da se ohranijo izjemne naravne in kulturne vrednote, zavaruje avtohtono rastlinstvo, živalstvo in naravni ekosistemi ter značilnosti neživega sveta, zagotovita $z$ naravnimi danostmi in vrednotami usklajen nadaljnji razvoj kmetijstva in gozdarstva, ohrani in razvija kulturna krajina ter zagotovijo razvoj in materialni pogoji za življenje in delo prebivalcev $v$ osrednjem delu Julijskih Alp, omogočita delovnim ljudem in občanom ter drugim obiskovalcem uživanje naravnih in kulturnih vrednot ter rekreacija $\mathrm{v}$ naravi $\mathrm{v}$ tem prostoru in dopolni dosedanje varovanje, se s tem zakonom določi osrednji del Julijskih Alp za naravni park pod imenom Triglavski narodni park. Cilji iz prejšnjega odstavka se uresničujejo $\mathrm{z}$ razvijanjem gospodarskih in družbenih dejavnosti $\mathrm{v}$ skladu $\mathrm{s}$ sprejetimi planskimi akti in $\mathrm{z}$ varstvenimi ukrepi, določenimi s prepovedmi in omejitvami v tem zakonu ter drugimi predpisi.«

- 7. ČLEN (PRVI DEL): »Razvoj naravnih in $\mathrm{z}$ delom pridobljenih vrednot na območju narodnega parka se uresničuje tako, da samoupravne organizacije in skupnosti, družbene organizacije ter društva in družbenopolitične skupnosti v svojih planskih aktih upoštevajo cilje narodnega parka: ....«

- 8.C̆LEN: »SR Slovenija in občine $\mathrm{z}$ območja narodnega parka v dolgoročnih planih opredelijo razvoj narodnega parka ter določijo sestavine kot obvezno izhodišče za pripravo in oblikovanje srednjeročnih planov.«

- $\quad$ 10.ČLEN, prvi odstavek: »Na osnovi in v skladu s planskimi akti se za območje narodnega parka sprejme skupni program razvoja narodnega parka.«

Sklepi, do katerih sem prišel pri ocenjevanju Zakona $\mathrm{z}$ vidika razvoja in tudi uresničevanja Zakona na tem področju, so naslednji:

- Zakon uvodoma sicer govori o tem, da je namen ustanavljanja TNP tudi gospodarski razvoj, toda $v$ nadaljevanju temu ne namenja nobene pozornosti več. Medtem ko so v Zakonu natančno določene naloge varstva narave, zagotavljanje nadzora in ustanovitev organizacije za varstvo narave, ki bi vse to izvajala, zaman iščemo zakonska določila, ki bi opredeljevala naloge in nosilce pospeševanja razvoja. Zdi se, da je zakonodajalec, ko je v uvodnem delu zakona sicer opredelil razvojne cilje parka, nato $\mathrm{v}$ nadaljevanju na vse to pozabil in se bolj posvetil le prepovedim in omejitvam. 
- Uresničevanje Zakona je tudi pokazalo, da se izvaja predvsem varstvena funkcija parka, medtem ko je razvoj območja ostal zgolj prazna obljuba. Ni bil sprejet skupni program razvoja narodnega parka. Še danes Triglavski narodni park nima načrta upravljanja. Deluje le na podlagi letnih programov dela, ki vsebujejo predvsem naravovarstvene naloge. Ni prišlo do oblikovanja in izvajanja skupnega pospeševanja razvoja v občinah, kjer leži Triglavski narodni park. Država tudi ni oblikovala nobenih posebnih sistemskih ali programskih ukrepov na nivoju države. Skratka, razvoj v Triglavskem narodnem parku se je doslej začel in končal z nekaj opredelitvami v prvih členi Zakona o Triglavskem narodnem parku.

\section{DINAMIČNI OKVIR PODJETNIŠTVA V NARAVNIH PARKIH}

Stopnja varovanja območja, ki je določena z zakonom o naravnem parku, je statični del okvira, načela trajnostnega razvoja pa so tisti dinamični del, v okviru katerih se razvija podjetništvo $\mathrm{v}$ naravnem parku.

Model trajnostnega (sonaravnega) razvoja sem izbral kot dinamični okvir podjetništvu v naravnih parkih. Načela trajnostne družbe so predstavljena v poglavju o trajnostnem razvoju, na tem mestu pa posebej razčlenjujem tiste vidike tega modela, ki so izhodišča podjetniškega delovanja. Ker model še ni povsem razvit, lahko govorimo le o načelih in usmeritvah.

- Podjetništvo $\mathrm{v}$ naravnih parkih mora izhajati iz temeljnega načela trajnostne družbe, to je spoštovanje občestva življenja in odgovornosti zanj. Gre za zavesten pristop, ki v podjetniško delovanje vključuje etiko (odgovornost, spoštovanje).

- Cilji podjetniškega delovanja so širši od običajnega temeljnega cilja podjetništva in sicer ustvarjanja profita. Poleg tega cilja, brez katerega ni podjetništva, je potrebno tudi upoštevati kakovost življenja, ki seveda ni samo v zagotavljanju materialnih virov.

Ohranjanje vitalnosti in pestrosti Zemlje je tudi ena izmed pomembnih prvin kakovosti življenja in zato posredno tudi ena izmed usmeritev podjetniškega delovanja.

- Obseg podjetniškega delovanja je skladno s sprejeto etiko omejen z nosilnimi zmogljivostmi določenega prostora. 


\section{ANALIZA PODJETNIŠTVA V TNP}

V širšem območju Triglavskega narodnega parka ležijo alpske doline, ki so stalno poseljene. Prebivalstvo teh dolin se je stalno zmanjševalo, tako da je ob ustanovitvi TNP prebivalo v parku 2395 stalnih prebivalcev, deset let kasneje pa le 2157. Konec leta 1998 je po registru prebivalstva v TNP živelo še 2132 stalnih prebivalcev. V petih občinah, Bledu, Bohinju, Bovcu, Kranjski gori in Tolminu, kjer so naselja $v$ TNP, je 20 naselij. Od teh je najmanjše Bavšica pri Bovcu (15 prebivalcev), največje pa Stara fužina v Bohinju (574 prebivalcev). Analiziral sem podjetja in samostojne podjetnike, katerih sedež je na območju TNP oziroma v naseljih, ki so znotraj TNP.

V Triglavskem narodnem parku je v letu 1997 poslovalo 26 gospodarskih družb in 49 samostojnih podjetnikov. Skupaj torej 75 gospodarskih subjektov, ki delujejo na naslednjih območjih:

- $\quad 49 \%$ v občini Bovec: $30 \mathrm{v}$ dolini Trente, $7 \mathrm{v}$ dolini Koritnice,

- $\quad 37 \%$ v občini Bohinj: 3 na Pokljuki, 25 ob Bohinjskem jezeru,

- Zgornja Radovna (edino naselje v občini Kranjska Gora, ki je v TNP): sedež 8 samostojnih podjetnikov,

- občina Kobarid nima nobenega naselja v TNP,

- občina Tolmin ima dve naselji $\mathrm{v}$ TNP, toda $\mathrm{v}$ teh naseljih nima sedež nobena gospodarska družba oziroma fizična oseba.

$62 \%$ vseh gospodarskih subjektov deluje v turizmu in gostinstvu, $15 \%$ pa v trgovini, ki pa je deloma vključena $v$ turistično dejavnost, deloma pa služi oskrbi krajevnega prebivalstva. Ostala podjetja delujejo v obrti, gradbeništvu, kmetijstvu in storitvah. Glede na razpoložljivost podatkov sem posebej analiziral gospodarske družbe in samostojne podjetnike.

\subsection{Gospodarske družbe v TNP}

Trenutno deluje na območju TNP 26 gospodarskih družb.Gibanje števila podjetij v zadnjem sedemletnem obdobju nam prikazuje tabela 1.

Tabela 1 :Število podjetij v TNP v obdobju 1991-1997

\begin{tabular}{|l|c|c|c|c|c|c|c|}
\hline Občina & 1991 & 1992 & 1993 & 1994 & 1995 & 1996 & 1997 \\
\hline Občina Bohinj & 8 & 8 & 15 & 18 & 18 & 18 & 18 \\
\hline Občina Bovec & 3 & 3 & 3 & 4 & 5 & 6 & 8 \\
\hline S k u p a j & $\mathbf{1 1}$ & $\mathbf{1 1}$ & $\mathbf{1 8}$ & $\mathbf{2 2}$ & $\mathbf{2 3}$ & $\mathbf{2 4}$ & $\mathbf{2 6}$ \\
\hline
\end{tabular}


Skupno število podjetij se je v obdobju samostojne Slovenije povečalo. To velja predvsem za območje občine Bovec, naselja Log pod Mangrtom, Lepene in Soče. V občini Bohinj pa se število podjetij ne povečuje že vse od leta 1994. Kljub temu je v občini Bohinj $69 \%$ vseh podjetij v TNP.

Pomanjkanje delovnih mest $\mathrm{v}$ naseljih Triglavskega narodnega parka je zelo pereč problem, za to je zelo pomembno, koliko delavcev zaposlujejo podjetja. Podatke o gibanju zaposlenih nam kaže tabela 2 .

Tabela 2 :Število zaposlenih v podjetjih na območju TNP v obdobju 1991 - 1997

\begin{tabular}{|l|c|c|c|c|c|c|c|}
\hline Občina & 1991 & 1992 & 1993 & 1994 & 1995 & 1996 & 1997 \\
\hline Občina Bohinj & 190 & 182 & 202 & 215 & 222 & 226 & 193 \\
\hline Občina Bovec & 0 & 3 & 4 & 0 & 3 & 5 & 7 \\
\hline S k u p a j & $\mathbf{1 9 0}$ & $\mathbf{1 8 5}$ & $\mathbf{2 0 6}$ & $\mathbf{2 1 5}$ & $\mathbf{2 2 5}$ & $\mathbf{2 3 1}$ & $\mathbf{2 0 0}$ \\
\hline
\end{tabular}

V obdobju od leta 1991 do leta 1997 se je število delovnih mest povečalo za 5\%. Ob tem je treba poudariti naslednje:

- Število delovnih mest $\mathrm{v}$ podjetjih na območju TNP v občini Bovec je zelo skromno, vendar se povečuje, predvsem zaradi novoustanovljenih malih podjetij.

- $\quad$ kar 97\% vseh delovnih mest v TNP se nahaja v občini Bohinj v naseljih Ribčev laz in Ukanc; tri (nekdanja družbena) podjetja zaposlujejo kar 76\% vseh delavcev v TNP, vendar se pri njih število delovnih mest znižuje, povečujejo pa se delovna mesta pri novoustanovljenih malih podjetjih.

Jasnejšo sliko o delovnih mestih dobimo, ko razvrstimo podjetja po velikostnih razredih glede na število zaposlenih.

Tabela 3 :Število podjetij po velikostnih razredih zaposlenih 1997

\begin{tabular}{|l|c|c|c|c|c|c|c|}
\hline Občina & brez zap. & 1 do 5 & 6 do 20 & 20 do 50 & 50 do 100 & nad 100 & skupaj \\
\hline Občina Bohinj & 9 & 5 & 1 & 2 & 1 & 0 & 18 \\
\hline Občina Bovec & 4 & 4 & 0 & 0 & 0 & 0 & 8 \\
\hline S k u p a j & $\mathbf{1 3}$ & $\mathbf{9}$ & $\mathbf{1}$ & $\mathbf{2}$ & $\mathbf{1}$ & $\mathbf{0}$ & $\mathbf{2 6}$ \\
\hline S k u p a j \% & $\mathbf{5 0}$ & $\mathbf{3 4}$ & $\mathbf{4}$ & $\mathbf{8}$ & $\mathbf{4}$ & $\mathbf{0}$ & $\mathbf{1 0 0}$ \\
\hline
\end{tabular}


Kar 50\% podjetij nima nobenega zaposlenega. To pomeni, da za zdaj ta podjetja ne nudijo nobene možnosti zaposlovanja, ugotavljamo pa tudi, da so med njimi podjetja, ki svojo dejavnost ne opravljajo na območju TNP.

Že dosedanji podatki nam povedo, da obstajajo v TNP med gospodarskimi subjekti zelo velike razlike. Najbolj vidne so v:

- c času ustanavljanja in izvoru kapitala (pred letom 1991 ali po njem - nekdanji družbeni ali zasebni kapital),

- velikosti premoženja, obsegu poslovanja in številu zaposlenih,

- $\quad$ v ustreznosti in perspektivnosti razvoja v pogojih zavarovanega območja -TNP

Glede na njihov nastanek in dejavnost, velikost in pomembnost za nadaljnji razvoj sem jih razdelil $v$ tri skupine:

1. nekdanja družbena podjetja,

2. zadruge,

3. mala podjetja in samostojni podjetniki

\subsection{Problemi varstva narave in podjetništva $v$ TNP}

Preseganje sporov med varstvom narave in podjetništvom je možno le, če zasledujemo koncept celovitega varstva narave oziroma trajnostnega razvoja. Praksa nas na žalost opozarja, da smo od takšnega stanja še zelo daleč.

\subsubsection{Problemi varstva narave}

Probleme varstva okolja v TNP proučujemo $\mathrm{z}$ vidika virov onesnaževanja in njihovega negativnega vpliva na naravo. Onesnaževalci, ki se ne nahajajo v TNP, so predvsem proizvodnja (industrija), energetika in promet. Viri onesnaževanja v samem parku so gospodarske dejavnosti, promet in poselitev. Ključni problemi varstva narave so:

- onesnaževanje,

- obremenitve okolja,

- spremembe naravnih ekosistemov

Posledice teh pojavov se kažejo v ogroženosti vseh naravnih elementov: zraka, vode, tal, reliefa, rastlinstva in živalstva. V gradivu »Varstvo naravne in kulturne dediščine v Triglavskem narodnem parku - Analiza stanja 1981-1991 in cilji bodoče ureditve« (S. Della Valle, 1992) je ogroženost naravnih elementov opisna takole: »Zrak: zrak je občasno onesnažen na celotnem območju narodnega parka (regionalano ali čezmejno onesnaženje), pogosto in bolj izrazito pa v območju ali v neposredni bližini cestnih 
koridorjev.Voda: voda je dokaj močno onesnažena, kljub temu, da vsa izvira $\mathrm{v}$ območju Triglavskega narodnega parka...«

V gradivu so navedene tudi spremembe v reliefu. Navedeno je, da to sicer ne pomeni onesnaževanja okolja, vendar so to posegi v naravne razmere in povečujejo ranljivost pokrajine. Vse te spremembe abiotičnih elementov spreminjajo tudi življenjske razmere in s tem vplivajo tudi na rastlinski in živalski svet.

\subsubsection{Status narodnega parka postavlja podjetništvo $v$ drugačen položaj}

Čeprav status naravnega parka ne prinaša samo omejitev in prepovedi, se na tem mestu osredotočamo nanje. Popolnoma jasno je, da z uvedbo zavarovanega območja ustvarimo gospodarski prostor, ki je drugačen od tistega, ki velja za gospodarski prostor Slovenije. Zaščita narave pomeni hkrati tudi posebno omejevanje podjetništva in svobodo podjetniškega delovanja. S tem zapostavlja podjetnika oziroma podjetje, ki deluje na zavarovanem območju. Takšen položaj je nevzdržen, če ugotavljamo, da škode, ki ob tem nastajajo, niso ihkrati nadomeščene $\mathrm{z}$ odškodninami in koncesijami. Tega namreč obstoječa zakonodaja ne predvideva.

Obstoječe stanje v zavarovanih območjih je v nasprotju z Ustavo Republike Slovenije. Prvi stavek 74. člena Ustave Republike Slovenije, ki govori o podjetništvu se glasi: «Gospodarska pobuda je svobodna«. Ta svoboda pa je na zavarovanih območjih omejena, vendar $\mathrm{z}$ ničemer nadomeščena. To je tudi $\mathrm{v}$ nasprotju s tretjim odstavkom 71. člena Ustave, ki pravi: »Država skrbi za gospodarski, kulturni in socialni napredek prebivalstva na gorskih in hribovitih območjih.»

Rezultat teh omejitev so negativne posledice na podjetništvo in njegovo uspešnost. Učinki omejitev se kažejo v višjih stroških poslovanja in manjši donosnosti kapitala in dobičkonosnosti uporabljenih poslovnih sredstev.

Zakaj do tega prihaja?

- Omejevanje rabe naravnih virov zožuje prostor podjetniške dejavnosti,

- omejevanje rabe prostora (lokacije, prostor za dejavnosti) omejuje ali onemogoča izgradnjo poslovnih prostorov, omejuje podjetniško dejavnost $\mathrm{v}$ prostoru, ali povečuje stroške v zvezi s tem,

- omejitve obsega in načina poslovne dejavnosti povzročajo slabše poslovanje, velikokrat onemogočajo doseganje praga rentabilnosti in izkoriščanje prednosti ekonomije velikega obsega,

- dodatni pogoji npr. identiteta, pomenijo velikokrat dodatne stroške,

- dodatni postopki pomenijo dodatne ovire, daljši čas postopkov in s tem večje stroške 
Pozitivni učinki, ki jih prinaša status parka in njegovo delovanje pa so:

- $\quad$ ohranjanje narave, naravne in kulturne dediščine, ki je pomemben vir za razvoj podjetništva, zlasti na področju gostinstva in turizma,

- status parka je osnova, ki bi lahko pomenila posebno razvojno pomoč podjetništvu v TNP,

- uveljavljanje načel trajnostnega razvoja v TNP pomeni priložnost za krajevno prebivalstvo,

- omejitve obsega in področij delovanja podjetništva pomenijo tudi zmanjševanje konkurence in s tem ugodnejši položaj krajevnih podjetnikov.

\section{SKLEPI}

Proučevanje podjetništva v TNP bi moralo vsebovati še veliko drugih vidikov, ki v gradivu niso zajeti. Ne glede na to lahko na podlagi dosedanjega poznavanja te problematike zaključimo naslednje:

- $\quad$ podjetništvo v TNP je zelo skromno razvito, razen na območju Bohinja,

- Zakon o Triglavskem narodnem parku sicer načeloma predvideva tudi razvoj, vendar ne daje možnosti za njegovo dejansko uresničevanje, zaradi česar je tudi upravljanje TNP v glavnem lahko osredotočeno le na varstveno funkcijo,

- $\quad$ status in upravljanje parka pomenita za podjetništvo določene omejitve, toda hkrati tudi nove možnosti in priložnosti,

- $\quad$ stopnja razvoja podjetništva $v$ TNP je še zelo oddaljena od tistega obsega in kakovosti, ki ju je možno razviti v okvirih trajnostnega razvoja,

- $\quad$ stanje v TNP ne zadovoljuje željene stopnje varovanja narave ter naravne in kulturne dediščine, kakor tudi ne želja in potreb po hitrejšem razvoju podjetništva,

- preseganje sedanjega stanja je možno z uresničevanjem koncepta celovitega varstva narave, ki vključuje tudi trajnostni razvoj in s tem tudi razvoj podjetništva. 


\section{VIRI IN LITERATURA}

1. Anderson T., Folke C., Nystrom S., 1995: Trading with the Environment. Earthscan Publications Limited.

2. Cater E., Lowman G., 1994: Ecotuorism. Royal Geografical Society, London.

3. Dalla Valle S. in ost., 1992: Varstvo naravne in kulturne krajine v TNP. Bled.

4. Heukens N., 1993: Loving them to death?. FENNPE, Grafenau.

5. Keating M.,1995: 21 Agenda za spremembo. Umanotera, Ljubljana.

6. Mihalič T., 1995: Ekonomija okolja v turizmu. Ekonomska fakulteta, Ljubljana.

7. Munasinghe M., Mc Neely J.: Protected area economics and policy. World Bank and World Conservation Union (IUCN).

8. Munro A., 1991: Caring for The Earth. A Strategy for Sustainable Living, Gland.

\section{SUSTAINABLE DEVELOPEMENT AND ENTERPRENEURSHIP IN TRIGLAV NATIONAL PARK}

\section{Summary}

Sustainable development is the proper issiue to avoid conflicts betwen nature conservation and enterpreneurship. Static frame for enteropreneurship is Nature conservation act in our case also law on Triglav national parc.

Enterpreneurship in Triglav national parc is more developed only in Bohinj. There are 75 enterprises in Triglav national parc, mainly in tourism, agricoulture and craft. The concept of sustainable develpemnet is not yet enough applied in Triglav national park.

Conflicts which ocour betwen nature conservation and entreprenurship derived from the Law on Triglav national parc, which have to be adopted. Many times problems of underdeveloped entrepreneurship are cosed becouse of lack of knowledge of main principles of sustainable developement. Local people have to be much more engaged in the proceses of nature conservation and developement. 